\title{
COMMENTS
}

\section{Judicial Response to Governmental Loss or Destruction of Evidence}

The defendant in a criminal case learns that shortly after the crime occurred, government agents arrived at the scene and removed all pieces of evidence. The defendant moves to discover some evidence, which he contends is highly material to his defense. The government agency admits having taken possession of the evidence sought, but explains that it has since been lost or destroyed.

Many commentators on criminal procedure ${ }^{1}$ have recognized the problem of defining the scope of discovery of evidence by the defense. ${ }^{2}$

1 Vast amounts have been written on criminal discovery in general, including Brennan, The Criminal Prosecution: Sporting Event or Quest for Truth?, 1963 WASH. U.L.Q. 279; Everett, Discovery in Criminal Cases-In Search of a Standard, 1964 DukE L.J. 477; Fletcher, Pretrial Discovery in State Criminal Cases, 12 Stan. L. REv. 293 (1960); Goldstein, The State and the Accused: Balance of Advantage in Criminal Procedure, 69 Yale L.J. 1149 (1960); Kaufman, Criminal Discovery and Inspection of Defendant's Own Statements in the Federal Courts, 57 CoLum. L. REv. 1113 (1957); Louisell, Criminal Discovery: Dilemma Real or Apparent?, 49 CALIF. L. REv. 56 (1961); Louisell, The Theory of Criminal Discovery and the Practice of Criminal Law, 14 VAND. L. REv. 921 (1961); Miller, The Omnibus Hearing-An Experiment in Federal Criminal Discovery, 5 SAN Diego L. Rev. 293 (1968); Moran, Federal Criminal Rules Changes: Aid or Illusion for Indigent Defendant, 51 A.B.A.J. 64 (1965); Traynor, Ground Lost and Found in Criminal Discovery, 39 N.Y.U.L. REv. 228 (1964); Developments in the Law-Discovery, 74 HARv. L. REv. 940 (1961); Comment, Pretrial Discovery in Criminal Cases: A Necessity for Fair and Impartial Justice, 42 NEB. L. REv. 127 (1962); Comment, Protective Orders as a Safeguard in Broadened Criminal Discovery, 113 U. PA. L. REv. 1295 (1965); Comment, Toward Effective Criminal Discovery: A Proposed Revision of Federal Rule 16, 15 VILL. L. REv. 655 (1970).

2 The statutory basis of criminal discovery is rule 16 of the Federal Rules of Criminal Procedure and the Jencks Act, 18 U.S.C. § 3500 (1970). Rule 16 allows pretrial discovery by the defense of (1) any relevant written or recorded statements or confessions made by the defendant, results of examinations and tests, and recorded testimony of the defendant before a grand jury; (2) books, papers, documents, tangible objects, and buildings or places, upon a showing of materiality to the preparation of the defense and reasonableness. As sanctions for failure to comply with discovery orders, the court may "order [the] party to permit the discovery or inspection of materials not previously disclosed, grant a continuance, or prohibit the party from introducing in evidence the material not disclosed, or it may enter such other order as it deems just under the circumstances." The Jencks Act allows discovery by the defense of statements and reports of government witnesses after 
Tro connected and equally important problems, however, have not, as yet, been fully explored: when should sanctions be applied where there is a loss or destruction of admittedly discoverable evidence by a government agent prior to a trial, and, if a sanction is appropriate, what sanction may the court apply?

In dealing with the loss or destruction of evidence, courts have relied on cases from two general areas: those dealing with the suppression of evidence and those dealing with the destruction of interim notes. (Interim notes are notes made by a government agent that are later incorporated into a final report. $)^{3}$ This comment, after reviewing the reasoning and sanctions utilized in these two types of cases, will analyze their application to the destruction-of-evidence situation. Finally, a new approach suggested by a recent case, United States $\boldsymbol{v}$. Bryant, ${ }^{4}$ will be explored.

\section{Sources of Judicial Analysis and Authority}

\section{A. Suppression-of-Evidence Cases}

Along with the duty to comply with pretrial discovery orders, ${ }^{5}$ the prosecution has the related duty to disclose ${ }^{6}$ to the accused information that would be helpful in preparing ${ }^{7}$ or presenting ${ }^{8}$ his defense. ${ }^{9}$

the witnesses have testified on direct examination in the trial of the case. If the government fails to comply with a Jencks Act order, "the court shall strike from the record the testimony of the witness ... unless the court ... shall determine that the interests of justice require that a mistrial be declared."

3 In these cases, the term "interim notes" is not the courts'. It is used in this comment to distinguish between notes incorporated into a formal report before being destroyed (interim notes) and notes destroyed without incorporation (which are treated as "destruction-of-evidence" cases).

4439 F.2d 642 (D.C. Cir. 1971).

6 See note 2 supra.

6 See generally Cannon, Prosecutor's Duty to Disclose, 52 MarQ. L. Rev. 516 (1969); Ginsburg, Disclosure to the Defense in a Criminal Case, 57 In.. B.J. 194 (1968); Note, The Duty of the Prosecutor to Disclose Exculpatory Evidence, 60 Colum. L. REv. 858 (1960); Comment, Disclosure and Discovery in Criminal Cases: Where Are We Headed?, 6 DuQUESNE L. REv. 41 (1967); Note, Discovery and Disclosure-Dual Aspects of the Prosecutor's Role in Criminal Procedure, 34 Geo. Wash. L. Rev. 92 (1965); Note, The Prosecutor's Duty to Disclose Exculpatory Evidence, 19 OxLA. L. Rev. 425 (1966); Comment, Criminal Discovery Implications of the False Evidence and Suppression of Evidence Cases, 34 TENN. L. REv. 654 (1967); Note, The Prosecutor's Constitutional Duty to Reveal Evidence to the Defendant, 74 YALE L.J. 136 (1964).

7 Ashley v. Texas, 319 F.2d 80, 85 (5th Cir.), cert. denied, 375 U.S. 931 (1963). The prosecutor has a duty to disclose evidence that would be significant to the defendants "in planning and conducting their defense." See Note, The Prosecutor's Constitutional Duty to Reveal Evidence to the Defendant, supra note 6, at 145-46.

8 E.g., Brady v. Maryland, 373 U.S. 83 (1963) (evidence showing that confederate and not defendant had done the actual killing); Levin v. Clark, 408 F.2d 1209 (D.C. Cir. 1967) 
The duty to disclose extends to any evidence in the possession of the government $t^{10}$ that would be material ${ }^{11}$ to the defense.

In the leading case in this area, Brady $v$. Maryland, ${ }^{12}$ the Supreme Court indicated that the withholding or suppression of material evidence by the government is a violation of due process. In Brady, a murder case, the prosecution withheld from the defense a statement made by the defendant's confederate in which the confederate admitted that he had done the actual killing. At the trial, the accused conceded that he had participated in the crime, but pleaded against capital punishment on the ground that he had not done the actual killing. Since the statement of the confederate would have aided the defense in mitigating the punishment, the Court held the suppression of the statement to be a violation of due process. ${ }^{13}$

The aim of the Court in Brady was to secure a fair trial for the defendant rather than to punish the government for its misconduct. ${ }^{14}$ The

(evidence going to the credibility of a key government witness); Barbee v. Warden, Md. Penitentiary, 331 F.2d 842 (4th Cir. 1964) (reports of ballistics and fingerprint tests made by police department that would have tended to exculpate the defendant).

8 Both courts and commentators have noted the large disparity in resources between the government and the defendant in gathering evidence. E.g., Levin v. Clark, 408 F.2d 1209, 1211 (D.C. Cir. 1967): "The Government's facilities for discovering evidence are usually far superior to the defendant's. This imbalance is a weakness in our adversary system which increases the possibility of erroneous convictions." Jackson v. Wainwright, 390 F.2d 288, 294 (5th Cir. 1968); Application of Kapatos, 208 F. Supp. 883, 888 (S.D.N.Y. 1962). Goldstein, supra note 1 , at 1182-83, notes: "Even [the defendant's] search for evidence at large is inevitably restricted because he has neither a crime laboratory nor vast identification and fingerprint files available to him. Most often, he has no investigative assistance whatever." See 8 J. Moore, Federal Practice đf 16.02[1] (2d ed. 1970); Traynor, supra note 1, at 229; Note, Discovery and Disclosure-Dual Aspects of the Prosecutor's Role in Criminal Procedure, supra note 6, at 105; Note, The Prosecutor's Duty to Disclose Exculpatory Evidence, supra note 6, at 428-29; Comment, Criminal Discovery Implications of the False Evidence and Suppression of Evidence Cases, supra note 6, at 663; Note, The Prosecutor's Constitutional Duty to Reveal Evidence to the Defendant, supra note 6, at $142-43$.

10 The duty to disclose has been held to apply to the police and other government officials as well as the prosecution. In Barbee v. Warden, Md. Penitentiary, 331 F.2d 842, 846 (4th Cir. 1964), the court stated that "it makes no difference if the withholding is by officials other than the prosecutor. The police are also part of the prosecution, and the taint on the trial is no less if they, rather than the State's Attorney, were guilty of the nondisclosure." The court added, $i d$., that "[t]he duty to disclose is that of the state, which ordinarily acts through the prosecuting attorney; but if he too is the victim of police suppression of the material information, the state's failure is not on that account excused." See Curran v. Delaware, 259 F.2d 707, 712-13 (3d Cir. 1958); Imbler v. Craven, 298 F. Supp. 795, 806 (C.D. Cal. 1969), cert. denied, 400 U.S. 865 (1970); Note, The Prosecutor's Duty to Disclose Exculpatory Evidence, supra note 6, at 428.

11 For a discussion of what constitutes "material" evidence, see text and notes at notes 23-34 infra.

12373 U.S. 83 (1963).

$13 \mathrm{Id}$. at 86.

14 Some sanctions in the area of criminal procedure are imposed to punish the police 
imposition of sanctions where material evidence has been suppressed, according to the Court, "is not punishment of society for the misdeeds of a prosecutor but the avoidance of an unfair trial to an accused."15 The unfairness of the trial was held to derive from the materiality of the evidence suppressed and not from the motivation behind the suppression:

We now hold that the suppression by the prosecution of evidence favorable to an accused upon request violates due process where the evidence is material either to guilt or to punishment, irrespective of the good faith or bad faith of the prosecution. ${ }^{10}$

State and lower federal courts have followed this approach, ignoring the circumstances surrounding the nondisclosure ${ }^{17}$ and the good or bad faith of the prosecution. ${ }^{18}$ Where the information withheld would have been helpful to the defense, its suppression is recognized as

rather than to separate the guilty from the innocent. A clear example of this is the exclusion of coerced confessions. See generally Kadish, Methodology and Criteria in Due Process Adjudication-A Survey and Criticism, 66 YALE L.J. 319, 346-47 (1957).

15373 U.S. at 87.

$16 \mathrm{Id}$. Although the Court mentioned a request by the defense for the information sought, it does not appear that the element of request is decisive, at least not where the evidence in question is highly material to the defense. In Giles v. Maryland, 386 U.S. 66, 102 (1967), Justice Fortas, concurring, stated: "I see no reason to make the result turn on the adventitious circumstance of a request. If the defendant does not know of the existence of the evidence, it may not be able to request its production." Cases in which the court granted relief without a request by the defense include Barbee v. Warden, Md. Penitentiary, 331 F.2d 842, 845 (4th Cir. 1964) (evidence withheld tending to exculpate defendant); United States ex rel. Meers v. Wilkins, 326 F.2d 185, 137 (2d Cir. 1964) (evidence withheld tending to exculpate defendant); and State v. Fowler, 101 Ariz. 561, 564, 422 P.2d 125, 128 (1967) (evidence withheld would have aided defense of self-defense); see Levin v. Katzenbach, 363 F.2d 287, 291 n.13 (D.C. Cir. 1966); In re Ferguson, 5 Cal. 3d 525, 532, 487 P.2d 1234, 1239, 96 Cal. Rptr. 594, 599 (1971); Hanson v. Cupp, 484 P.2d 847, 849 (Ore. App. 1971); 8 J. MOore, supra note 9, I 16.06[1]; Cannon, supra note 6, at 517; Comment, Criminal Discovery Implications of the False Evidence and Suppression of Evidence Cases, supra note 6 , at $662-63$.

17 See United States v. Consolidated Laundries Corp., 291 F.2d 563 (2d Cir. 1961). The fact that the suppression is the result of nondisclosure by the police rather than the prosecutor has been held to be irrelevant. See authorities cited note 10 supra.

18 In Jackson v. Wainwright, 390 F.2d 288, 295 (5th Cir. 1968), the court stated: "In accord with Brady lower federal courts have emphasized the harm to the defendant rather than the prosecutor's motive in failing to disclose exculpatory evidence." United States v. Miller, 411 F.2d 825, 832 (2d Cir. 1969); Levin v. Clark, 408 F.2d 1209, 1211 (D.C. Cir. 1967); Levin v. Katzenbach, 363 F.2d 287, 290 (D.C. Cir. 1966); Barbee v. Warden, Md. Penitentiary, 331 F.2d 842, 846 (4th Cir. 1964); United States ex rel. Meers v, Wilkins, 326 F.2d 135, 139 (2d Cir. 1964); United States v. Consolidated Laundries Corp., 291 F.2d 563, 571 (2d Cir. 196I); In re Ferguson, 5 Cal. 3d 525, 532, 487 P.2d 1234, 1238, 96 Cal. Rptr. 594, 598 (1971); State v. Vigliano, 50 N.J. 51, 60-61, 232 A.2d 129, 134 (1967); Hanson v. Cupp, 484 P.2d 847, 850 (Ore. App. 1971); Means v. State, 429 S.W.2d 490, 494 (Tex. Crim. App. 1968); see Note, Discovery and Disclosure-Dual Aspects of the Prosecutor's Role in Criminal Procedure, supra note 6, at 102; Note, The Prosecutor's Constitutional Duty to Reveal Evidence to the Defendant, supra note 6, at 141-42. 
equally harmful regardless whether the nondisclosure resulted from innocence, negligence, or guile.

Before the court will impose sanctions for the suppression of evidence, however, the defense ${ }^{19}$ must demonstrate that the nondisclosure resulted in prejudicial error. ${ }^{20}$ Courts regard the nondisclosure of information to be harmless error where the defense fails to show the materiality of the evidence sought ${ }^{21}$ or where the defense counsel was independently aware of and had access to the evidence. ${ }^{22}$

The scope of "materiality" has not yet been delineated by the Supreme Court. In Giles v. Maryland, ${ }^{23}$ in which the prosecution had withheld information concerning the prosecutrix's promiscuity and mental instability from the defense in a rape case, the Supreme Court remanded the case for further consideration. The Court expressly left open the question "whether the prosecution's constitutional duty to disclose extends to all evidence admissible and useful to the defense, and the degree of prejudice which must be shown to make necessary

19 The burden is on the defendant to demonstrate the materiality of the evidence sought. See note 21 infra.

20 Where the prosecution acts in bad faith, some courts have maintained that it is not necessary for the defense to show prejudice to be entitled to relief. If the suppression was the result of negligence or accident, however, the defendant must show that the nondisclosure prejudiced his defense. United States v. Keogh, 391 F.2d 138, 146-47 (2d Cir. 1968); Levin v. Clark, 408 F.2d 1209, 1210-11 (D.C. Cir. 1967); Barbee v. Warden, Md. Penitentiary, 331 F.2d 842, 847 (4th Cir. 1964); Kyle v. United States, 297 F.2d 507, 514 (2d Cir. 1961), cert. denied, 358 U.S. 937 (1964); United States v. Consolidated Laundries Corp., 291 F.2d 563, 570-71 (2d Cir. 1961); see Note, Discovery and Disclosure-Dual Aspects of the Prosecutor's Role in Criminal Procedure, supra note 6, at 103.

21 In Giles v. Maryland, 386 U.S. 66, 98 (1967), Justice Fortas, concurring, stated the general attitude of the courts:

This is not to say that convictions ought to be reversed on the ground that information merely repetitious, cumulative, or embellishing of facts otherwise known to the defense or presented to the court, or without importance to the defense for purposes of the preparation of the case or for trial was not disclosed to defense counsel. It is not to say that the state has an obligation to communicate preliminary, challenged, or speculative information.

Where the information withheld is found to lack materiality, the conviction will be affirmed. E.g., United States v. Keogh, 440 F.2d 737 (2d Cir. 1971), cert. denied, - S. Ct. -; United States v. American Radiator \& Standard Sanitary Corp., 433 F.2d 174 (3d Cir. 1970), cert. denied, 401 U.S. 948 (1971); United States v. Crisona, 416 F.2d 107 (2d Cir. 1969), cert. denied, 397 U.S. 961 (1970); Luna v. Beto, 395 F.2d 35 (5th Gir. 1968), cert. denied, 394 U.S. 966 (1969); United States v. Tomaiolo, 378 F.2d 26 (2d Cir.), cert. denied, 389 U.S. 886 (1967); In re Imbler, 60 Cal. $2 d$ 554, 387 P.2d 6, 35 Cal. Rptr. 293 (1963), cert. denied, 379 U.S. 908 (1964); Means v. State, 429 S.W.2d 490 (Tex. Crim. App. 1968); see Note, Discovery and Disclosure-Dual Aspects of the Prosecutor's Role in Criminal Procedure, supra note 6, at 103.

22 E.g., Rosenberg v. United States, 360 U.S. 367, 371 (1958); Thomas v. United States, 343 F.2d 49, 54 (9th Cir. 1965); see United States ex rel. Thompson v. Dye, 221 F.2d 763, 767 (3d Cir.), cert. denied, 350 U.S. 875 (1955); Means v. State, 429 S.W.2d 490, 495 (Tex. Crim. App. 1968).

23386 U.S. 66 (1967). 
a new trial." ${ }^{44}$ State and lower federal courts have defined "materiality" broadly and in varying ways. ${ }^{25}$ It has been defined as "evidence which ... might have led the jury to entertain a reasonable doubt about [the defendant's] guilt,"28 "information impinging on a vital area in [the] defense,"27 information "vital to the defense of the accused,"28 "evidence that may reasonably be considered admissible and useful to the defense,"29 and "pertinent facts relating to [the] defense."30 Evidence pertaining to the credibility of a key government witness has also been held to be material. ${ }^{31}$ Although the admissibility of the information as evidence will be considered in determining its materiality to the defense, $^{32}$ a number of courts have stated that the mere inadmissibility of the information sought does not automatically render it immaterial. ${ }^{33}$ Courts have also noted that in cases of doubt, the usefulness of the evidence is to be determined by the defense and not by the prosecution. ${ }^{34}$

24 Id. at 74.

25 In Giles v. Maryland, 386 U.S. 66, 98 (1967), Justice Fortas, concurring, noted that the state is compelled to disclose any information "which is material, generously conceived, to the case, including all possible defenses." See Levin v. Clark, 408 F.2d 1209, 1212 (D.C. Cir. 1967); Note, Discovery and Disclosure-Dual Aspects of the Prosecutor's Role in Criminal Procedure, supra note 6, at 103; Note, The Prosecutor's Constitutional Duty to Disclose Evidence to the Defendant, supra note 6, at 148-49.

26 Levin v. Katzenbach, 363 F.2d 287, 291 (D.C. Cir. 1966) (evidence relating to credibility of government witness).

27 United States ex rel. Butler v. Maroney, 319 F.2d 622, 627 (3d Cir. 1963) (statement given by defendant to police relevant for impeachment of key government witness).

28 United States ex rel. Thompson v. Dye, 221 F.2d 763, 765 (3d Cir.), cert. denied, 350 U.S. 875 (1955). Dye involved an arresting officer's statement to the prosecutor that the defendant had been under the infuence of liquor at the time of the arrest. The defendant admitted the killing, but argued that he lacked the necessary mental intent for first degree murder due to his drunken state. The prosecutor called as a witness another police officer, who testified that the defendant was not drunk at the time of the arrest.

29 Griffin v. United States, 183 F.2d 990, 993 (D.C. Cir. 1950) (information that an open pen knife was found in murder victim's pocket where defendant pleaded self-defense).

30 Curran v. Delaware, 259 F.2d 707, 711 (3d Cir. 1958) (information relating to credibility of government witness).

31 E.g., United States v. Miller, 411 F.2d 825, 832 (2d Cir. 1969); Levin v. Katzenbach, 363 F.2d 287, 291-92 (D.C. Cir. 1966); United States v. Consolidated Laundries Corp., 291 F.2d 563, 569-70 (2d Cir. 1961); Curran v. Delaware, 259 F.2d 707, 712 (3d Cir. 1958); In re Ferguson, 5 Cal. 3d 525, 533-34, 487 P.2d 1234, 1240-41, 96 Cal. Rptr. 594, 599-600 (1971); cf. Napue v. Illinois, 360 U.S. 264 (1959); People v. Savvides, I N.X.2d 554, 557, 136 N.E.2d 853, 854-55, 154 N.Y.S.2d 885, 887 (1956).

32 Comment, Criminal Discovery Implications of the False Evidence and Suppression of Evidence Cases, supra note 6, at 666.

33 See Giles v. Maryland, 386 U.S. 66, 98 (1967) (Fortas, J., concurring); United States v. Gleason, 265 F. Supp. 880, 886 (S.D.N.Y. 1967); Comment, Criminal Discovery Implications of the False Evidence and Suppression of Evidence Cases, supra note 6, at 665-66; Note, The Prosecutor's Constitutional Duty to Reveal Evidence to the Defendant, supra note 6 , at 147 .

34 In Griffin v. United States, 183 F.2d 990, 993 (D.C. Cir. 1950), the court stated the 
Although the burden of demonstrating the materiality of the evidence is on the defense, this burden is relatively light due to the broad interpretation given to materiality by the courts. Moreover, the evidence withheld is typically still in existence at the time the suppression is discovered ${ }^{35}$ and is, therefore, easily analyzable by the court.

Where the court finds that the suppression has resulted in prejudicial error, the sanction imposed is generally a new trial. ${ }^{36}$ In this way, the defendant is able to prepare and present a defense with access to all material information. ${ }^{37}$ The government, on the other hand, is not required to let a guilty man go free.

\section{B. Destruction-of-Interim-Notes Cases}

In the cases involving the destruction of interim notes, the factual situation is basically the same. Typically, a government agent has recorded data pertaining to the case or has taken notes while interviewing a witness who later testifies at the trial. ${ }^{38}$ These notes are incorporated into a formal report. The agent then deliberately destroys the original notes and gives the defense a copy of the final report. The defense moves for discovery of the original notes. ${ }^{39}$ For the purposes

general attitude: "When there is substantial room for doubt, the prosecution is not to decide for the court what is admissible or for the defense what is useful." E.g., United States v. Consolidated Laundries Corp., 291 F.2d 563, 570 (2d Cir. 1961); Note, The Prosecutor's Constitutional Duty to Disclose Evidence to the Defendant, supra note 6, at 148.

35 This may be merely a matter of definitions. The courts may be labeling as "suppression" only those cases in which the evidence is in existence at the time the nondisclosure is discovered and as "destruction" those cases in which it is not. In all of the cases cited in the preceding notes on suppression, the evidence was in existence.

36 E.g., Brady v. Maryland, 373 U.S. 83 (1963); United States v. Miller, 411 F.2d 825 (2d Cir. 1969); Jackson v. Wainwright, 390 F.2d 288 (5th Cir. 1968); Levin v. Clark, 408 F.2d 1209 (D.C. Cir. 1967); United States ex rel. Butler v. Maroney, 319 F.2d 622 (3d Cir. 1963); United States v. Consolidated Laundries Corp., 291 F.2d 563 (2d Cir. 1961); United States ex rel. Thompson v. Dye, 221 F.2d 763 (3d Cir.), cert. denied, 350 U.S. 875 (1955); Griffin v. United States, 183 F.2d 990 (D.C. Cir. 1950); Smith v. Urban, 245 Ark. 781, 434 S.W.2d 283 (1968); State v. Vigliano, 50 N.J. 51, 232 A.2d 129 (1967); Hanson v. Cupp, 484 P.2d 847 (Ore. App. 1971).

37 This assumes, of course, that the evidence is in existence. See note 35 supra.

38 The vast majority of these cases involve notes from an interview with a government witness. E.g., Killian v. United States, 368 U.S. 231 (1961), rehearing denied, 368 U.S. 979 (1962); United States v. Lepiscopo, 429 F.2d 258 (5th Cir.), cert. denied, 400 U.S. 948 (1970); United States v. Covello, 410 F.2d 536 (2d Cir.), cert. denied, 396 U.S. 879 (1969); United States v. Baker, 358 F.2d 18 (7th Cir.), cert. denied, 385 U.S. 869 (1966); United States v. Lonardo, 350 F.2d 523 (6th Cir. 1965); United States v. Spatuzza, 331 F.2d 214 (7th Gir.), cert. denied, 379 U.S. 829 (1964); Ogden v. United States, 323 F.2d 818 (9th Cir. 1963), cert. denied, 376 U.S. 973 (1964); United States v. Tomaiolo, 317 F.2d 324 (2d Cir. 1963); United States v. Greco, 298 F.2d 247 (2d Cir.), cert. denied, 369 U.S. 820 (1962); United States v. Thomas, 282 F.2d 191 (2d Cir. 1960). Where the notes represent substantially verbatim statements, they are within the purview of the Jencks Act. See note 2 supra.

39 The defense may move for discovery under rule 16 or the Jencks Act. See note 2 supra. 
of this comment, only those cases will be considered in which the court either holds or assumes that the original notes, if they were in existence, would be discoverable.

The leading case in this area is Killian $v$. United States, ${ }^{40}$ in which interim notes from an interview with a government witness were destroyed after allegedly being fully incorporated into a final report. The Supreme Court remanded the case to the district court for a hearing to determine whether the destruction of the interim notes had violated due process or the defendant's rights under the Jencks Act. ${ }^{41}$ The district court was instructed to make findings on three matters: (1) whether the notes were made for the purpose of transferring data, (2) whether the agent acted in good faith in destroying the notes, and (3) whether the agent acted in accordance with the normal procedure of the governmental unit in destroying the notes.

If the agents' notes of [the government witness's] oral reports of expenses were made only for the purpose of transferring the data thereon to the receipts signed by [the government witness], and if, after having served that purpose, they were destroyed by the agents in good faith and in accord with their normal practice, it would be clear that their destruction did not constitute an impermissible destruction of evidence nor deprive [the defendant] of any right. ${ }^{42}$

If, on the other hand, the district court were to find any of the above elements lacking, the defendant would be entitled to a new trial. ${ }^{43}$

The Supreme Court expressly stated that the harmless error doctrine was applicable to this type of case. ${ }^{44}$ Not all destructions of evidence are per se violations of due process or discovery rights. ${ }^{45}$ There must be a showing of actual harm to the defendant before a new trial will be granted. 46

Lower federal courts have uniformly followed the Killian approach where there has been a destruction of interim notes. ${ }^{47}$ The burden of

40368 U.S. 231 (1961).

41 See note 2 supra.

42368 U.S. at 242.

43 Id. at 244. If the defendant were able to show bad faith on the part of the agent, this would apparently be sufficient to warrant a new trial even if he could not show conclusively that the original notes differed from the final report. Proof of bad faith without proof of variance in the reports, however, would be difficult, if not impossible, to produce since variance would be the major external evidence of bad faith.

44 Id. at 243-44.

$45 \mathrm{Id}$. at 242.

46 Id. at 243-44.

47 E.g., United States v. Fruchtman, 421 F.2d 1019 (6th Cir.), cert. denied, 400 U.S. 849 (1970); United States v. Lepiscopo, 429 F.2d 258 (5th Cir.), cert. denied, 400 U.S. 948 (1970); United States v. Covello, 410 F.2d 536 (2d Cir.), cert. denied, 396 U.S. 879 (1969); 
showing lack of full incorporation of the notes into the final report is generally placed on the defense. In the absence of such a showing by the accused, courts typically find that the notes were fully transcribed and that, therefore, material evidence was not withheld from the defense. The good faith of the government agent and the observance of normal procedures are regularly stressed. Since evidence of the agent's motives can come only from the agent himself, courts, for the most part, appear to accept without question the agent's statement that he acted in good faith. Similarly, courts generally do not explore the type or efficiency of the evidence preservation rules followed by the government agency involved, ${ }^{48}$ but rather accept the agency's statement that the destruction of interim notes is "normal procedure." 49 In the vast majority of the interim notes cases, courts have, upon a finding of full incorporation, good faith, and observance of normal practices, affirmed convictions. ${ }^{50}$

United States v. Baker, 358 F.2d 18 (7th Cir.), cert. denied, 385 U.S. 869 (1966); United States v. Comulada, 340 F.2d 449 (2d Cir.), cert. denied, 380 U.S. 978 (1965); Alexander v. United States, 336 F.2d 910 (D.C. Cir.), cert. denied, 379 U.S. 935 (1964); United States v. Spatuzza, 331 F.2d 214 (7th Cir.), cert. denied, 379 U.S. 829 (1964); Ogden v. United States, 323 F.2d 818 (9th Gir. 1963), cert. denied, 376 U.S. 973 (1964); United States v. Tomaiolo, 317 F.2d 324 (2d Cir. 1963); United States v. Greco, 298 F.2d 247 (2d Cir.), cert. denied, 369 U.S. 820 (1962); United States v. Thomas, 282 F.2d 191 (2d Cir. 1960); United States v. Hilbrich, 232 F. Supp. 111 (N.D. Ill. 1964), aff'd, 341 F.2d 555 (7th Cir.), cert. denied, 381 U.S. 941 (1965).

48 The Fourth Circuit has, however, at least twice warned in dicta (in each case the destroyed notes were held to be not within the purview of the Jencks Act) that it was not satisfied with the agency's explanation that the destruction was in accord with "normal procedure." In United States v. Johnson, 337 F.2d 180, 201-02 (4th Gir. 1964), aff'd on other grounds, 383 U.S. 169 (1966), the court stated:

This is not the first time that a court has been called upon to consider the effect of the destruction of FBI interview notes. [Citations.] Each time the problem has arisen the FBI has claimed that the notes were destroyed as part of FBI routine. This is really not a satisfactory answer. Where the agent testifies to a matter he claims not to be in the notes and the defendant insists on a different version, an issue arises which may not be satisfactorily resolved in the absence of the original notes. If the notes were available, they might confirm or refute one version or the other. . . Eliminating the uncertainty may serve the interest of the Government no less than the defendant.

And in United States v. Missler, 414 F.2d 1293, 1304 (4th Cir. 1969), cert. denied, 397 U.S. 913 (1970), the court noted: "[W]e do agree that the FBI's practice is subject to criticism and introduces opportunity for the assertion of doubt. Retention of the notes would foreclose many attempts to impeach FBI agents' reports."

49 Conceivably, the defendant could introduce independent evidence on the failure of the agent to follow the agency's "normal procedures," but not necessarily on the efficiency of the procedures followed. No case has been found in which the defense introduced evidence on either matter.

50 A number of courts have expressed the view that the police cannot be forced to retain all possible evidence. The basic notion was stated by Justice Frankfurter, concurring in Campbell v. United States, 365 U.S. 85, 102 (1961): "Nothing in the legislative history of 
The emphasis in Killian and by lower federal courts on the good faith of the agent and the observance of normal procedures in the interim notes cases appears to be in sharp contrast to the total irrelevancy of these aspects in the suppression cases. Although courts in the interim notes cases talk in terms of good faith and normal procedures, however, it may be that the decisive factor in these cases-as in the suppression cases-is the materiality of the evidence of which the defendant has been deprived. On the one hand, the defendant in an interim notes case typically does not point to any particular information left out of the final report. On the other hand, since the notes have been destroyed, the court cannot be absolutely certain, as it can in a suppression case, in which the evidence sought is still in existence, that the error is harmless. The notes may well have contained additional information that would have been helpful to the defense, but that the defense does not know of and cannot show because of the destruction. Faced with this tension between the defendant's failure to show a particular harm and the government's inability to demonstrate conclusively that there was full incorporation, the courts may be using the agent's good faith and observance of normal practices as resolving factors. ${ }^{51}$ Were the defendant able to show a lack of full incorporation, the reference to good faith and the circumstances of the loss would be unnecessary - the probability of a deprivation of material information would be much less remote.

The view that the materiality of the evidence destroyed is actually the decisive factor is supported by United States $v$. Lonardo. ${ }^{52}$ In Lonardo, a stenographer had taken down verbatim the statements of the witnesses as they were interviewed by the government agent. At the trial, the stenographer testified that the final report prepared by the agent omitted some statements included in the original notes. The interim notes had been destroyed by the agent shortly before the trial

the [Jencks] Act remotely suggests that Congress' intent was to require the Government, with penalizing consequences, to preserve all records and notes taken during the countless interviews that are connected with criminal investigation by the various branches of the Government."

51 The Supreme Court has not yet specified the extent to which the good or bad faith of the agent in destroying the notes will be determinative of the application of sanctions. In Campbell v. United States, 365 U.S. 85 (1961), after the Court remanded the case to the district court for further hearings to determine whether the interim and final notes were within the purview of the Jencks Act, the Court noted, but did not answer this question. Id. at 98. And in Campbell v. United States, 373 U.S. 487 (1963), the Court, although holding that the final report was within the scope of the Jencks Act, expressly declined to reach the question whether the destruction of the interim notes, if done in good faith, was sanctionable. $I d$. at 491 n.5.

52350 F.2d 523 (6th Cir. 1965). 
commenced. The court found the failure to incorporate fully the original notes into the formal report sufficient in itself to warrant reversal. ${ }^{53}$ The court deemed it unnecessary to consider the good or bad faith of the agent ${ }^{54}$ or the observance of normal procedures ${ }^{55}$ where the defense had been deprived of significant information:

In the case before us we see no need to characterize the destruction of these statements as in good faith or bad-as honest or corrupt. These were no long lost documents or clerical filing errors. The destruction was deliberate; it was on the eve of the trial; it was accomplished by the government agent in charge of preparing evidence for the prosecution of the case. The fact that the agent who destroyed them may have done so in reliance upon FBI regulations (or in good faith belief that such existed) does not alter the nature of the sanctions imposed by the statute. ${ }^{56}$

Where interim notes are destroyed without full incorporation, ${ }^{57}$ the appropriate sanction is a new trial. ${ }^{58}$ Where the notes pertained to an interview with a government witness, the testimony of that witness will be excluded at the trial. ${ }^{59}$ If the witness in question is central to the prosecution's case, the exclusion of this testimony may lead the prosecution to dismiss the case. ${ }^{60}$

\section{Destruction-of-Evidence Cases}

A defendant moves for discovery of certain evidence and is told that it has been lost or destroyed by a government agency. The defendant

53 Id. at 527-28. Killian was expressly distinguished by the court in Lonardo on this ground. Id. See also Lee v. United States, 368 F.2d 834 (D.C. Cir. 1966); text and notes at notes $66-68$ infra.

54 The dissent in Lonardo notes, 350 F.2d at 532: "No error of judgment or good faith belief in the propriety of destroying such a statement by any government employee will permit escape from the sanctions of the Jencks Act, unless 'the very same information' has somehow been preserved in another form."

55 The dissent gives a detailed description of the routine followed by the agent in destroying the notes and his stated reasons for so doing. Id. at 535-36.

56 Id. at 529 .

57 Under the language of Killian, a showing of bad faith or failure to observe normal procedures on the part of the agent would be sufficient to warrant a new trial. Demonstrating bad faith without showing failure to incorporate, however, would be extremely difficult. See note 43 supra. And it may well be that the incorporation or lack thereof is the actual focal point of these cases. See text and note at note 51 supra.

58 Killian v. United States, 368 U.S. 231, 244 (1961); United States v. Lonardo, 350 F.2d 523,529 (6th Cir. 1965).

59 The Jencks Act provides as sanction the striking of the witness's testimony or declaring a mistrial. See note 2 supra.

60 The court in Lonardo recognized, 350 F.2d at 529, that the exclusion of the witness's testimony might "frustrate this prosecution." The dissent similarly noted, id. at 532, that "[i]]n the case at bar, application of this rule may well be tantamount to dismissal because the government must rely upon the witnesses ... to sustain its case." 
contends that without this evidence, he cannot possibly present an adequate defense; his right to a fair trial has been violated by the actions of the government agency. The prosecution argues that since the evidence no longer exists, its potential usefulness for the defense can never be definitely ascertained. It is unfair to society to let the defendant go free solely because of the loss or destruction of one piece of evidence of unascertainable value. Faced with this situation, the court must decide whether sanctions are appropriate and, if so, which sanction is proper for this particular case.

The type of evidence sought varies in the destruction cases. It may be needed as part of the affirmative defense or for impeaching a government witness. If it is part of the affirmative defense, the evidence may have directly proven the defendant's innocence or it may have only supported his general version of the occurrence. Similarly, the conduct of the government agent may vary; he may have acted from good faith, negligence, or guile.

\section{A. Cases Adapting the Suppression Approach}

In Trimble $v$. State, ${ }^{61}$ the court applied the analysis developed in the suppression cases to the problem of loss or destruction of evidence by the government. ${ }^{62}$ In Trimble, a minister had been convicted of the first-degree murder of the chairman of the Board of Stewards of the church. The prosecution had charged that the killing had resulted from an argument between the defendant and the deceased over certain debts owed by the defendant. The defendant minister claimed that he had killed in self-defense when the deceased had attempted to strike him with a table during an argument concerning improper advances made by the deceased to the defendant's wife. The evidence in question was a copy of a letter written by the minister to his superior allegedly concerning the improper advances and a tape recording that, according to the defendant, contained a conversation between the deceased and the defendant's wife in which the deceased made indecent suggestions. By the time of the trial, the letter was lost and the tape erased by the police.

The court in Trimble, as did the courts in the suppression cases, placed its major emphasis on the potential materiality and usefulness of the missing evidence and not on the motives of the government agent or the circumstances of the loss and destruction: "The presence and existence of the letter and tape recording in order to prove or

6175 N.M. 183, 402 P.2d 162 (1965).

62 The court in Trimble recognized, however, id. at 186, that the destruction of evidence was "not strictly a suppression of evidence in the sense that the term is generally used." 
substantiate defendant's version of the reason for the argument between decedent and himself and to support his claim of self-defense would seem to be too apparent for argument."63 At the same time, the court recognized that if the recording had been preserved and did not contain the alleged conversation, the prosecution's version of the incident would have been supported. ${ }^{64}$ The court concluded, however, that the potential materiality of the destroyed evidence was sufficient to warrant a reversal and specifically noted that the lack of bad faith on the part of the government agent was irrelevant: "The state ... argues that since the 'suppression' was negligent and not wilful, a different rule applies. That this is not true under the facts here present would seem to be clear in what was said in Brady v. State of Maryland ...."."65

Disregard of the good faith of the government agent is seen again in Lee v. United States. ${ }^{6 B}$ In Lee, certain reports within the scope of the Jencks Act had been destroyed without being incorporated into other reports. These reports were relevant to the testimony of two government witnesses, who stated that they could not remember the precise scope of the dealings in question without consulting the reports. The court reversed the conviction on the ground that under these circumstances, the trial court should have struck the testimony of the government witnesses, regardless of their good faith in destroying the reports: "Neither is there any reason to think that the destruction of the reports occurred in bad faith or otherwise than in an ordinary course of business devoid of any conscious purpose to hamper the defense. But the Jencks Act does not embody in terms any 'good faith' exception ...." 67 The interim notes cases were expressly distinguished on the ground that there was no incorporation of notes in the present case. ${ }^{68}$

The sanctions imposed by courts applying the suppression approach in the destruction-of-evidence situation have varied with the nature of the evidence lost or destroyed. Where the evidence represented an affirmative portion of the defense, as in Trimble, courts have held that the case must be dismissed.69 Where, however, it would have had value

63 Id. at 190 .

64 Id. at 187 .

65 Id. at 189 .

66368 F.2d 834 (D.C. Cir. 1966).

67 Id. at 837 .

$68 \mathrm{Id}$. at 838 n.7.

69 Trimble v. State, 75 N.M. 183, 190-91, 402 P.2d 162, 168 (1965). See also United States v. Heath, 147 F. Supp. 877 (D. Hawaii 1957), appeal dismissed, 260 F.2d 623 (9th Cir. 1958), which was expressly followed by the court in Trimble. In Heath, a tax evasion case in which certain of the defendant's records necessary for his defense were lost by government agents, the court held that the indictment would be dismissed. Heath was based not on 
only in impeaching a government witness, the court may, as in Lee, order a new trial in which the testimony of the government witness will be excluded.

\section{B. Cases Adapting the Interim Notes Approach}

Some courts, in dealing with the problem of loss or destruction of evidence, have used an approach similar ${ }^{70}$ to that employed in the interim notes cases. These courts have emphasized the conduct of the government agent and the circumstances of the loss more than the usefulness of the evidence to the defense. ${ }^{71}$

The leading case employing this approach is United States $v$. Augenblick, ${ }^{72}$ which involved a collateral attack on a court-martial conviction through an action for back pay alleging a constitutional defect in the military decision..$^{73}$ At the court-martial, the defense had moved under the Jencks Act $^{74}$ for discovery of a tape recording made during interrogation of the key government witness. The tape, however, could not be found. The court of claims rendered judgment for the defendant on the ground that the trial court had failed to require that the government prove that the destruction was done in good faith. ${ }^{75}$ The Supreme Court reversed, holding that where the government adequately explained the loss of the evidence, the denial of discovery was not a violation of due process. ${ }^{76}$

The Court in Augenblick looked not to the possible usefulness of the missing tapes to the defense ${ }^{77}$ but to the conduct of the government agents and the procedures followed in handling the tapes. ${ }^{78}$ The

the suppression-of-evidence approach, but rather on "the accused's right to a fair trial." Id. at 879 .

70 These courts do not necessarily cite the interim notes cases, but follow the general approach of those cases, emphasizing the good faith of the agent and the circumstances of the loss. These factors were wholly ignored in the suppression cases.

71 The court may be using the good faith of the agent as the basis for its decision when the materiality of the evidence is unclear. See text and note at note 51 supra; text at notes 83-88 infra.

72393 U.S. 348 (1969).

73 The Supreme Court assumed, for the purposes of argument, that such an attack may be made. $I d$. at $351-52$.

74 See note 2 supra.

75 Augenblick v. United States, 377 F.2d 586 (Ct. Cl. 1967). The court interpreted Killian as holding that good faith is the determinative aspect in applying sanctions in all destruction situations. Id. at 598. It held that the burden of showing good faith is on the government. $I d$.

78393 U.S. at $355-56$.

77 The Supreme Court did not expressly refer to Killian in reaching its decision, but followed the Killian approach, emphasizing the good faith of the agent and the procedures followed. Id. at $355-56$.

78 The court of claims had examined in detail the potential usefulness of the tapes for 
Court noted that the government had introduced testimony on "the Navy's routine in handling and using such recordings" and that "an earnest effort was made to locate them."79 The record of the case was found to be "devoid of credible evidence that [the tapes] were suppressed," 80 referring apparently to bad faith supression. Although the Court expressly held that "the Government bore the burden of producing [the tapes] or explaining why it could not do so,"81 the government's explanation in this case was deemed to be adequate, even though the whereabouts of the tapes remained a "mystery." 82

A similar emphasis on the good faith of the government agents is seen in State $v$. Maloney. ${ }^{83}$ In Maloney, a first-degree murder case, the defendant, a fifteen-year-old boy, claimed that the killing of his mother and stepfather occurred after the stepfather had discovered the defendant in bed with his mother following sexual intercourse between the mother and the defendant. The evidence sought by the defense was a "used" condom, which the defense argued would, under scientific examination, show that the defendant had in fact engaged in sexual relations with his mother and, thereby, support his contention that the killing was done in self-defense when his stepfather became enraged. ${ }^{84}$ The condom, however, had been thrown away by the investigating officers who found the bodies.

The court in Maloney dismissed the potential usefulness of the condom to the defense as "mere speculation." 85 The court's primary emphasis was placed on the good faith of the agents: ${ }^{86}$

[The agents] could not then have known that defendant was to later claim that his stepfather had discovered him and his mother in an act of sexual intercourse. Nor could they have known ... that such evidence might tend to exonerate the accused. Certainly the destruction thereof was not the result of guile. ${ }^{87}$

In order for sanctions to be imposed, the agents "must know, or have

impeaching the key government witness, whose "veracity was obviously questioned by the members of the court-martial." 377 F.2d at 605 .

79393 U.S. at 355 .

$80 \mathrm{Id}$. at 356.

$81 . I d$. at $355-56$.

82 Id. at 355.

83105 Ariz. 348, 464 P.2d 793, cert. denied, 400 U.S. 841 (1970).

84 According to the defendant, the mother was either accidentally or deliberately shot by the father when she tried to stop the fight. Id. at 350 .

85 Id. at 351 .

86 The court did refer to the suppression cases, but nevertheless went on to stress the good faith of the agents. $I d$.

87 Id. 
reason to know, that the evidence being destroyed was either material or favorable to the accused."'s8

Courts following the interim notes approach have not indicated what sanctions will be applied should the loss of evidence be found to be the result of a bad faith destruction. Presumably, the sanctions would be similar to those imposed by courts following the suppression approach. Where the evidence related to the testimony of a government witness, as in Augenblick, that testimony should be excluded from the trial. Where the evidence would have affirmatively supported the defense, as in Maloney, it might be necessary to dismiss the case. ${ }^{80}$

\section{Critique of Application of Suppression and Interim Notes Approaches}

The problem with applying the reasoning of either the suppression cases or the interim notes cases is that the loss or destruction of evidence is simply neither animal. Loss or destruction is not suppression, which involves evidence still in existence, and the evidence is not interim in nature.

The destruction situation has, to be sure, elements similar to each of the two areas. As in the suppression case, the defendant in the destruction situation has been forced, because of actions of a government agent, to go to trial without the benefit of evidence that he contends would have been useful to his defense. The possible good faith of the agent is largely irrelevant $t^{90}$ to the defendant in both the suppression and destruction contexts where he has been deprived of material evidence. And, as in the interim notes case, the evidence sought has been destroyed.

The destruction situation, however, differs significantly from both the suppression and interim notes cases. In the suppression case, the evidence, because it is still in existence, is easily analyzable. The court's total concentration on the materiality of the evidence is sensible. In the destruction situation, however, determining the usefulness of the evidence for the defense becomes more tenuous due to its nonexistence. Unlike the interim notes case, there is no incorporation of the evidence lost. Because of this absence of both incorporation and the assumption of harmless error that incorporation produces, the use of

$88 \mathrm{Id}$. at 352.

89 It may be possible, where the evidence would at most only substantiate the defendant's general story, but would not directly prove him innocent, for the court to instruct the jury that it must accept the story as true. See text and note at note 124 infra.

90 The agent's good faith would be relevant to the defendant only in the sense that if the agent has destroyed the evidence in bad faith, there is a greater chance that the evidence would have been helpful to the defendant. 
good faith and adherence to normal procedures as determinative factors is less justifiable in the destruction situation. There is the added. danger that courts applying the interim notes approach to the destruction situation may, as they have in the interim notes cases, accept without question the government agent's statement that he acted in good faith and that the destruction was in accordance with normal practices.

Neither the suppression cases nor the interim notes cases indicate fully what sanctions are appropriate in the destruction situation. In both the suppression and interim notes cases, a new trial provides an adequate remedy for the defendant. In the suppression case, since the evidence sought is still in existence, a new trial allows the accused an opportunity to defend himself with access to all material evidence. ${ }^{91}$ In the interim notes case, should the court find it necessary to reverse the conviction, a new trial can be held with the testimony of the witness in question excluded.92 Simply providing a new trial without further instructions, however, will not provide an adequate remedy where the evidence destroyed is part of the defendant's affirmative defense. The accused will still be deprived of the evidence that he sought at the prior trial.

\section{United States v. Bryant}

United States $v$. Bryant ${ }^{93}$ presents another possible approach to the problem of loss or destruction of evidence. In Bryant, the defendants Bryant and 'Turner, together with Johnson (who did not appeal), had been convicted of offenses involving the sale of heroin. The sale was made to Pope, an undercover agent for the Bureau of Narcotics and Dangerous Drugs. Pope, the principal witness for the prosecution, testified at the trial that he and Johnson made the general arrangements in Pope's motel room for the sale of the heroin to Pope. On the following day, according to Pope, Johnson and Bryant visited Pope at his motel room. After some negotiations, Bryant approved the sale of a particular quantity of heroin at a particular price. Later the same day, Johnson, accompanied by Turner, came to Pope's motel room. According to Pope, the three of them had a general conversation about the narcotics business at this time. The three went to Johnson's home to pick up the heroin and subsequently returned to Pope's motel room, where payment was made. During the various conversations occurring

91 The court can apply this sanction liberally without fear of letting a guilty man go free. See text at note 37 supra.

92 There is a greater chance in the interim notes case than in the suppression case, however, that a reversal may lead to dismissal. See note 60 supra.

93439 F.2d 642 (D.C. Cir. 1971), noted in 1971 DUKE L.J. 644. 
in Pope's room, other government agents were in the next room listening and making a tape recording of the transaction.

The defense sought to discover the tape recording. The prosecution admitted that a tape had been made, but stated that it had been lost at the Bureau of Narcotics and Dangerous Drugs. At the hearing on the defense motion to discover the tape, the agent in charge of the taping admitted that he had made no effort to preserve the tape or to consult a superior regarding his decision not to preserve it.

The prosecution attempted to show at the trial that Bryant and Turner aided and abetted in the sale of heroin by Johnson. Pope's account of the motel room conversation and the roles allegedly played by the defendants became the basis of the government's case. ${ }^{94}$

Judge Wright, speaking for the Court of Appeals for the District of Columbia Circuit, recognized the relevance of the lost tapes with respect to the question of the defendant's guilt or innocence:

It is possible, after all, that the tapes might have revealed that there was no discussion whatever of a narcotics deal while appellants were in the motel room or that they in no way participated in the conversations. More probably, the tape might have clarified the context in which certain remarks were made or corrected other matters of emphasis and degree in Agent Pope's testimony. ${ }^{95}$

Yet the court did not, as in Trimble and Lee, impose sanctions on the ground that the evidence was highly relevant and "might have completely undercut the Government's case." 96 Rather, in determining whether sanctions should be imposed, the court expressly followed Augenblick and looked to the circumstances of the loss:

Augenblick not only makes clear that the circumstances of the tape's disappearance in these cases should be relevant to the question of proper sanctions. It also suggests that, while sanctions should be imposed in cases of bad faith suppression of evidence, an exception will be made for good faith loss. . . . An exception for good faith loss of important evidence must not be allowed to swallow the discovery rules, and the burden of explanation on the Government must be a heavy one; but criminal convictions otherwise based on sufficient evidence may be permitted to stand so long as the Government made "earnest efforts" to preserve crucial materials and to find them once a discovery request is made. ${ }^{97}$

94 The court in Bryant noted, id. at 645, that "[w]ithout Agent Pope's account of the motel room conversations, the Government would have almost no evidence against appellant Bryant and a much weaker case against appellant Turner."

85 Id. at $645-46$.

$98 I d$. at 648 .

97 Id. at 651 . 
Using this general framework, with its emphasis on governmental conduct, the court fashioned two solutions to the destruction-of-evidence problem: one for future cases and one for the case then before it.

For the future, the court directed the government agencies to promulgate and enforce rigorous and systematic rules regarding the preservation of all discoverable evidence. When the destruction situation arises in the future, the court stated, it will (1) examine the rules themselves to determine whether they are adequate for preserving all discoverable evidence and (2) inquire into the conduct of the particular agent to determine whether he has attempted in good faith to follow the rules:

[W]e hold that sanctions for nondisclosure based on loss of evidence will be invoked in the future unless the Government can show that it has promulgated, enforced and attempted in good faith to follow rigorous and systematic procedures designed to preserve all [court's emphasis] discoverable evidence gathered in the course of a criminal investigation. The burden ... is on the Government to make this showing. Negligent failure to comply with the required procedures will provide no excuse. ${ }^{98}$

The court emphasized that all discoverable evidence is, in the future, to be preserved by the governmental agencies. Since "there is no exception [to the general rule] for good faith administrative decision that certain evidence is not discoverable and thus need not be preserved," the court warned the government agencies that in framing their rules for evidence preservation, they "must define discoverable evidence very broadly, including any materials that 'might' be 'favorable' to the accused.",99

Since no such rules had previously been required, the court followed an approach similar to that used in the interim notes cases and Augenblick to deal with the particular case before it. Factors to be weighed in determining whether to impose sanctions included not only the importance of the evidence lost and the evidence of guilt adduced at the trial but also the degree of negligence or bad faith involved. The court remanded the case to the district court for further inquiry into these areas. ${ }^{100}$

In Bryant, the court did not make clear what sanctions it will apply in the future where there is a loss or destruction of evidence. For the case then before it, the court recognized that the only possible sanc-

98 Id. at 652.

99 Id. at $652 \mathrm{n} .21$.

100 Id. at 653. 
tion, should it be found necessary to apply one, would be a new trial with the testimony of Pope excluded.101 The court noted, however, that this would be tantamount to dismissing the case "since without the testimony there would be no case."102

On remand, ${ }^{103}$ the district court, after holding a hearing, found that the lost tape had been played by the agents and discovered to be wholly unintelligible. The district court affirmed the convictions and the case was once again appealed.

In the second appeal of the case, ${ }^{104}$ the court of appeals further expanded its ruling with respect to future cases. The court repeated its warning that all discoverable evidence must, in the future, be preserved and expressly stated that this included both intelligible and unintelligible tapes. ${ }^{105}$ The court noted that "if the Bureau's rule had allowed nonpreservation of tapes ... judged by an agent to be unintelligible, it would have violated the principles we set forth . . . ."106 The court concluded that if the present case arose in the future, the negligent conduct of the agent in failing to preserve the unintelligible tape "would surely result in imposition of full sanctions."107

In the case then before it, the court held, however, that the convictions should stand. Under the "more pragmatic" approach used for the present case, the court found that "the unintelligibility of the tapeswhen combined with the very strong evidence of guilt adduced at trial-outweighs the negligence involved in the loss of the tape."108

\section{E. Critique of the Bryant Approach for Future Cases}

The chief advantage of the Bryant approach for future cases lies in its demand for rigorous and systematic rules for evidence preservation. ${ }^{109}$ In this respect, it remedies the major drawback of the Killian line of cases: the tendency of the courts to accept, with little, if any, further inquiry, the government agent's statement that he acted in good faith and in accord with normal practices. Under the Bryant approach, a court will compare the agent's action and the procedure

101 Id. This is the sanction provided in the Jencks Act. See note 2 supra.

102 Id.

103331 F. Supp. 927 (D.D.C. 1971).

104448 F.2d I182 (D.C. Cir. 1971). It is interesting to note that the same panel of judges (Wright, MIcGowen, and Johnson) decided both Bryant appeals.

105 Id. at 1184 n.l.

$100 \mathrm{Id}$.

107 Id. at 1184. The sanction would be a new trial with Pope's testimony excluded. This would probably lead to dismissal since the prosecutor's case was based almost entirely on Pope's testimony.

$108 \mathrm{Id}$.

109 The court's demand in Bryant for systematic rule making by government agencies 
prescribed by the agency and decide for itself whether the agent's conduct was actually in accord with normal practices. More important, the Bryant approach allows the court to review the rules established by the agency to determine if they effectively preserve evidence. As Judge Wright stated, "regular procedures for preservation must be adequate for the task; systematic non-preservation of tapes . . . might be regular, but would be insufficiently protective of defendants' right to discovery." 110 The Bryant approach is an attempt to bring structure and systematic rules to the pretrial period, which the court saw to be "a dark no-man's land of unreviewed bureaucratic and discretionary decision making." 111

There are, however, some serious problems with the Bryant approach for future cases. First, the court may be placing an almost impossible burden on the government agencies. The impracticality comes not in the demand for systematic and rigorous rules; this is clearly a demand that should have been made long ago. ${ }^{112}$ The impracticality arises, rather, from the court's repeated warning that all discoverable evidence must be preserved. While this is a desirable goal, it may be realistically impossible to effect due to the extremely broad range of discoverable evidence. ${ }^{113}$ When a government agent comes to the scene of a crime, he cannot know which objects present might be material or useful to the defense. ${ }^{114}$ The Bryant rule would appear to demand that everything at the crime scene be preserved.

A second disadvantage of the Bryant approach arises from the fact that the imposition of sanctions will depend largely on the conduct of the government agent and not on presence of prejudicial error to the defendant. ${ }^{115}$ In its second opinion, the Bryant court specifically stated that if the same case arose in the future, the court would, because of the agent's negligence, impose sanctions even though there was strong evidence of guilt adduced at the trial and the nondisclosed tape, being unintelligible, probably would have been of little value to the defense. This approach can perhaps be justified on the ground that without the threat of sanctions, the government agencies would not

has been expressly approved in K.C. Davis, Administrative LAw Text 50, 151 (3d ed. 1972).

110439 F.2d at 652.

111 Id. at 644 .

112 See K.C. Davis, Discretionary Justice 84-96 (1969).

113 See note 2 supra.

114 A number of courts have held that the prosecution may not decide for the defense what is material. See text and note at note 34 supra.

115 For a discussion of the emphasis placed in the suppression cases on prejudicial error, see text and notes at notes 19-22 supra. 
rigorously enforce and follow the rules of evidence preservation.116 The opposite side of the coin, however, is much less easy to justify. No sanctions will be imposed where the agency has adhered to all requisite rules of evidence preservation even though the evidence lost or destroyed, according to the defendant, would have been exculpatory. In looking only at the circumstances of the loss or destruction, the court ignored the one factor crucial to the defendant: the usefulness of this particular evidence to this particular defendant. Where evidence important to the defense of the accused is lost or destroyed, the harm to the defendant is the same regardless of the good faith of the government agent. ${ }^{117}$

Finally, the court in Bryant failed to indicate what range of sanctions trial courts could apply in the future. The court recognized that an infraction of the Jencks Act ${ }^{118}$ would result in the striking of the testimony of the witness whose prior statement has been lost. It offered no indication, however, of what sanction is proper where evidence pertaining to an affirmative defense has been lost or destroyed by government agents.

\section{F. A Proposed Alternative}

Logically, the test for determining when to impose sanctions for the loss or destruction of evidence should turn on the materiality of the evidence to the defense. ${ }^{119}$ As long as the defendant can show some particular harm ${ }^{120}$ resulting from the deprivation of the evidence, some sanction should be imposed to correct the harm to the defendant. As the courts in the suppression cases ${ }^{121}$ have long recognized, the good faith of the government agent is largely irrelevant where the evidence is material to the accused. The only situation in which the motives of the agent should be considered is where the defense shows that the agent acted in bad faith. ${ }^{122}$ The court may, upon such a showing, pre-

116 See note 14 supra.

117 For a discussion of the possible relevance to the defense of the agent's good faith, see note 90 supra.

118 See note 2 supra.

110 Since the evidence in question no longer exists, an analysis of its materiality will admittedly not always be easy.

120 When the defendant can show neither a particular harm nor bad faith on the part of the government agent, no sanction will be applied.

121 See text and note at notes 14-18 supra.

$122 \mathrm{Bad}$ faith on the part of the government agent is relevant in the application of sanctions in that it gives rise to a suggestion that the evidence destroyed would have been material to the defense. Presumably, an agent acting in bad faith will destroy those pieces of evidence that he regards as helpful to the defense. No such presumption of materiality arises, however, if the destruction was the result of negligence. 
sume the materiality of the evidence and place the burden of proving nonmateriality on the prosecution. ${ }^{123}$

The range of sanctions available to the trial court should be broad ${ }^{124}$ since the type of evidence and the degree of materiality can vary greatly in destruction situations. In some cases, the prior existence of the object but not the object itself may be important to the defense. ${ }^{125}$ Here, the government agent's statement in court that such an object was found at the scene will be sufficient to insure an adequate defense. ${ }^{126}$ Where the evidence would have been part of an affirmative defense and the defense makes some, albeit not a particularly strong, showing of specific materiality, the court may wish to use a missingevidence instruction. The jury would be instructed that it may, but need not, presume that the evidence would have shown what the defense claimed it would. ${ }^{127}$ In another type of case, the defense may make a strong showing of materiality of the evidence for supporting the accused's general version of the occurrence, although not for proving his innocence directly. Here, the court may wish to instruct the jury that that particular aspect of the defense's case must be taken as established fact. Where the defense makes a strong showing that the evidence would directly establish his innocence, the court may find it necessary to dismiss the case entirely. ${ }^{128}$ If the evidence is relevant only for impeaching a government witness, then upon a showing of particular harm by the defense, ${ }^{129}$ the court may strike the witness's testimony. ${ }^{130}$ The court may demand a greater showing of harm in this last situation than where the evidence is relevant to the affirmative defense since the witness himself is still available to the defense.

123 The possibility of the defense showing bad faith on the part of the agent without showing the materiality of the evidence are slight since the chief evidence of bad faith would be, in most cases, the materiality of the evidence.

124 The courts may find guidance in the sanctions provided in the civil rules for noncompliance with discovery orders. FED. R. Grv. P. 37(b)(2) provides:

(A) An order that the matters regarding which the order was made or any other designated facts shall be taken to be established for the purposes of the action. ... (B) An order refusing to allow the disobedient party to support or oppose designated claims or defenses, or prohibiting him from introducing designated matters in evidence; (C) An order striking out pleadings or parts thereof, or staying further proceeding until the order is obeyed, or dismissing the action or proceeding or any part thereof, or rendering a judgment by default against the disobedient party ....

125 E.g., State v. Dabney, 181 Neb. 263, 147 N.W.2d 768 (1967) (defendant testified that deceased drew knife before the killing, and state's witness admitted at trial that knife was found at scene).

$128 I d$. at 269,147 N.W.2d at 772.

127 See generally 2 J. WIGMORE, EVDENCE 162-88 (3d ed. 1940).

128 See text and note at note 69 supra.

129 See text and notes at notes 52-56 supra.

130 See note 2 supra. 
Where the defendant can describe specifically the evidence he is seeking, ${ }^{131}$ but the government denies its prior existence, the court should place the burden of showing its nonexistence on the government. ${ }^{132}$ In this situation, the court may demand that the government offer evidence that some type of evidence preservation rules were being followed by the agency. Where the government is able to show the prior nonexistence of the evidence, clearly no sanction is necessary. Should the court find, however, that the evidence sought was in existence, as the defense contended, the court should apply one of the sanctions outlined above, depending on the degree of materiality of the evidence to the defense.

At present, appellate courts have not yet indicated the scope of sanctions open to trial courts. Offering a wide panoply of sanctions, as suggested above, may have the advantage of steering trial courts away from the extremes-no sanction or dismissal.

Under the proposed approach, the court's demand in Bryant for rigorous and systematic rules for evidence preservation need not be disregarded. Courts would be able to continue to apply sanctions where the loss or destruction was the result of negligence or bad faith. Under the proposed approach, however, these sanctions would be separate from those applied at the trial and would not benefit the defendant. Constructing such sanctions for disciplining the government agencies is beyond the scope of this comment. ${ }^{133}$

Regardless of the approach a court takes, the problem of loss or destruction of evidence is clearly a serious one. The various protections afforded the defendant at the trial will be of little benefit to him if he has no remedy for the loss or destruction of a material part of his defense by the government prior to the trial.

Jean Wegman Burns

131 Where the defense fails to specify the evidence that was allegedly lost or destroyed, courts have refused to apply sanctions. E.g., Hill v. United States, 374 F.2d 871 (9th Cir.), cert. denied, 389 U.S. 842 (1967).

132 Realistically, this would probably result in nothing more than a number of government agents testifying that the evidence sought was not at the scene of the crime.

133 See generally Comment, Actions Against Prosecutors Who Suppress or Falsify Evidence, 47 TEXAS L. REv. 642 (1969). 